\title{
WPS2582
}

\section{DEVELOPMENT FINANCING DURING A CRISIS: SECURITIZATION OF FUTURE RECEIVABLES}

\author{
Suhas Ketkar \\ Dilip Ratha
}

\author{
Economic Policy and Prospects Group \\ The World Bank \\ Washington, DC 20433
}

The views expressed in this paper are the authors' own and do not necessarily reflect those of the World Bank or its member countries. Comments are welcome and may be sent to dratha@worldbank.org. 


\section{Executive Summary}

During a liquidity crisis, developing countries need innovative ways to raise external finance. This research focuses on one such mechanism---asset-backed securitization of future-flow receivables---which provides a means of securing agency credit ratings for new issues that escape the sovereign ceiling and thereby reduce the cost of funding.

Since the first future flow securitization transaction was undertaken by Mexico's Telmex in 1987, the principal credit rating agencies have rated over 200 transactions with the aggregate principal amount totaling $\$ 47.3$ billion until the end of 1999 . Through an extensive cataloging of rated future flow receivable backed transactions and detailed discussions with rating agency professionals, Wall Street investment bankers, legal experts, and analysts in insurance companies, this study derives a number of conclusions about the rationale for using this asset class, its potential size as compared to its current size, and the prevalent constraints on its growth.

A typical future flow structure involves the borrowing entity selling its future product (receivable) directly or indirectly to an offshore Special Purpose Vehicle (SPV). The SPV issues the debt instrument. Designated international customers are directed to pay for the exports from the originating entity directly to an offshore collection account managed by a trustee. The collection agent makes principal and interest payments to the investors and directs excess collections to the originator.

The innovative structuring of these transactions has allowed many investment grade borrowers in developing countries to pierce the sovereign credit ceiling and obtain financing at significantly lower interest costs and for longer duration. Besides, future flow securitizations also attract a much wider class of investors because of their investment grade rating. Moreover, by establishing a credit history for the borrower, these deals enhance the ability and reduce the costs of accessing capital markets in future.

From the investors' point of view, the attractiveness of this asset class lies in its good credit rating and its stellar performance in good and bad times. Defaults are extremely rare in this asset class despite frequent and repeated liquidity crises in

developing countries. Buy-and-hold investors (such as insurance companies) are attracted to this asset class.

Over three-quarters of rated asset-backed transactions during 1987-99 have involved future flow receivables. This mode of financing has increased since the Mexican peso crisis in 1994-95. Latin American issuers have dominated this market: Mexico alone accounts for over one-half of asset-backed transactions; Argentina, Brazil and Venezuela account for another 34 percent.

Nearly one-half of the dollar amounts raised via future flow transactions are backed by oil and gas export receivables. But this asset class has demonstrated an 
enormous scope for creativity in non-oil sectors as well. In recent times, credit card and telephone receivables, workers' remittances, tax receivables and even export receivables to be generated by developing new investment projects have been securitized. The share of non-oil deals is much larger (over 83 percent) in terms of number of transactions rather than dollar amounts, since oil transactions tend to be large in dollar terms.

The size of future receivables of developing countries that are suitable for securitization is much larger than (more than six times) the current level of issuance at under $\$ 10$ billion annually. Of these receivables, a large part comes from outside Latin America, especially from countries in Eastern Europe and Central Asia that are rich in fuel and mineral exports. Countries in the Middle-East have large oil receivables. In South Asia, the potential for securitization lies in remittances, credit card vouchers, and telephone receivables.

A major constraint to the growth of future flow transactions arises from the paucity of good collateral in developing countries. Oil is an example of a good collateral for several reasons: a) the stock of oil in a country is more or less well-known; b) this is a highly 'liquid' asset with well-developed global markets, c) it is usually of great importance to a nation's economy and, therefore, its exports are less vulnerable to government interference. Finally, crude oil may be better collateral than refined petroleum because the former cannot be easily diverted to foreign importers (obligors) not included in the securitized structure. In comparison, agricultural commodities tend to be more difficult to securitize, although the number of such deals has risen rapidly in recent years.

The paucity of good collateral is also reflected in the absence of high-quality public and private issuers in developing countries. Securitization deals tend to be complex and involve high preparation costs and long lead-times. The lack of legal clarity on bankruptcy procedures in many developing countries adds further complexity to these deals. In some cases, policy makers are simply not familiar with this mechanism. Many issuers are constrained by the burden of full disclosure of information in a timely fashion. Others worry about whether the use of future flow secured bonds will taint their creditworthiness.

Public policy to facilitate future flow-backed securitizations should focus on removing these constraints. Transaction costs may be reduced through expansion of the scale of these deals by planning a series of deals by the same issuer (the so-called master trust arrangement). Establishment and use of indigenous credit rating agencies to obtain domestic credit rating can also reduce transaction costs, although care has to be taken in mapping local rating scales to international scales. Certain segments of this asset classsuch as securitization of oil receivables - may be amenable to standardization and a cookie-cutter approach. Clarification of bankruptcy laws will be helpful for all financial deals including securitization. Also, educating policy makers and potential issuers would help promote this asset class. 
However, future flow securitization increases the level of inflexible debt which can affect the issuer's (and perhaps the nation's) creditworthiness. While this is a valid concern, the present issuance of securitized debt does not appear to have approached a critical level. For instance, rating agencies have not downgraded the sovereign credit ratings of either Mexico or Venezuela on account of their rising securitized debt even though these two countries have been most aggressive in issuing securitized debt. It appears that securitized debt can rise to around 15 percent of total debt of a developing country without necessarily jeopardizing the sovereign's overall creditworthiness. Nevertheless, such debt combined with debt from other preferred creditors can reduce the ability of a borrower to service debt.

Governments may find this asset class attractive because, when planned and executed ahead of time, it can provide a way of accessing markets during times of liquidity crisis. There are also significant externalities associated with future flow deals. By clarifying the legal and institutional environment surrounding a developing country issuer, such deals can pave the way for future deals by other issuers as well. Because of their investment grade rating, future flow deals attract a much wider class of investors than unsecured deals. Thus, future flow deals can improve market liquidity and reduce market volatility. That can generate added interest on the part of international investors in other asset classes or other borrowers. 


\section{Acknowledgements}

We would like to acknowledge financial support from the World Bank through an RSB grant. The views expressed in this paper are the authors' own and do not necessarily reflect those of the World Bank or its member countries.

We would like to thank Uri Dadush and Ashoka Mody of the Economic Prospects and Policy Group for extensive discussions and Arun Sharma and Hans Paris of IFC for providing important insights. Anthony Bottrill, Sara Calvo and Alejandro Izquierdo also made useful comments. This study relies extensively on interviews with professionals from rating agencies, investment bankers, legal firms and insurance companies active in the market for future flow securitization. In particular we would like to thank the following organizations and individuals for sharing their knowledge, information and views: Asset Guaranty Insurance Company (David Bigelow, Eric R. Van Heyst), Banco Santander (Shailesh S. Deshpande), Chase Securities Inc. (Mark A. Tuttle), Citibank (Radford C. West), Cleary, Gottlieb, Steen and Hamilton (Andres de la Cruz), Credit Suisse First Boston (David Anderson), Davis Polk \& Wardwell (E. Waide Warner, Jr., Sartaj Gill), Fitch IBCA, Duff and Phelps (Jill Zelter, Patrick Kearns, Suzanne Albers, Christopher Donnelly), J.P. Morgan (Hillary Ward), Moody's (Susan Knapp), Morgan Stanley Dean Witter (Sadek M. Wahba), Standard \& Poor's (Laura Feinland Katz, Gary Kochubka, Rosario Buendia, Kevin M. Kime), TIAA CREF (Sanjeev Handa). Also our special thanks to the organizers and participants of a workshop organized by Standard \& Poor's. 


\section{Introduction}

I.1 Developing countries are subject to frequent financial crises and volatility of external capital flows. During a liquidity crisis, developing country entities need to find innovative ways of securing foreign finance. ${ }^{1}$ This paper focuses on one such mechanism---asset-backed securitization of future-flow receivables. ${ }^{2}$ This method provides developing country entities a means of securing credit ratings that escape the sovereign ceiling, thereby improving access to long-term financing at low cost.

I.2 A close examination of future flow securitization is timely in the present context of reduced investor confidence in developing countries. Following a series of financial crises---Mexico in late 1994, East Asia in the second half of 1997, Russia in August 1998, and Brazil at the beginning of 1999---private debt and equity capital flows to developing countries have declined from $\$ 151$ billion in 1996 to $\$ 134$ billion in 1997 , $\$ 97$ billion in 1998 and $\$ 47$ billion in 1999, and the near-term prospects do not look promising (World Bank 2000).

I.3 Securitization transactions can be classified according to whether these are rated or not rated by major credit rating agencies, and within each of these categories, according to whether they involve existing assets or future receivables. This study focuses on rated transactions largely because of the availability of information. It is hard to obtain information on unrated securities issued by developing country entities which are typically underwritten by commercial banks that either keep them on their own books or distribute them through private placement.

I.3.1 Rated transactions possess several advantages over unrated deals. For instance, the achievement of a better credit rating than the sovereign ceiling allows issuers to raise funding at lower cost (spread) and longer maturity. In particular, achieving an investment grade credit rating for a transaction makes it attractive to a wider class of investors. Insurance companies, for instance, face basket limitations on how much of unrated debt they can hold, and hence prefer rated transactions. They are the principal source of demand for debt backed by future flow assets. However, rated transactions also involve some costs by requiring over-collateralization (to improve credit

\footnotetext{
${ }^{1}$ Other options of receiving credit ratings that escape the sovereign ceilings are dollarization a la Argentina and external guarantees. Dollarization could persuade the rating agencies to award the blue chip country borrowers credit ratings that are superior to the sovereign ceiling; but it requires the willingness to accept a policy straight jacket with potentially painful implications for the real economy. External guarantees, if structured properly, can enhance creditworthiness; but guarantors are not easy to find. Securitization of future hard currency receivables is one of the better options for obtaining finance during periods of relative liquidity scarcity. As discussed below, securitization deals are structured to mitigate several elements of credit risk and often resort to over-collateralization to obtain credit ratings that breach the sovereign ceiling.

${ }^{2}$ Securitization of existing assets as well as local currency securitization are available as additional means of raising finance. This paper does not focus on existing asset securitizations because they have accounted for less than one-fourth of all asset-backed dollar transactions. Local currency securitizations are increasing in importance and can be a big aid to the development of local capital markets. But since they do not raise foreign finance, their role is not taken up in this paper.
} 
rating), larger transaction costs and longer lead times, and more extensive disclosure of financial information.

I.4 This study focuses largely on transactions backed by future receivables originated by developing country entities ${ }^{3}$. This is because a) over three-quarter of securitized transactions from developing countries (in nominal dollar terms) have involved future flows; and b) compared to existing asset securitization, future flow securitizations are capable of making more capital available to developing country entities during periods of liquidity scarcity. ${ }^{4}$

I.5 The study relies on extensive interviews with investment bankers, professionals at credit rating agencies, lawyers specializing in securitization transactions, and analysts at insurance companies who provide complete or partial insurance against various risks associated with such transactions.

I.6 The main findings of this research report are:

1. Securitization of future flow and existing receivables can provide a way of raising development finance for many low and particularly middle-income countries, especially during times of low liquidity and heightened perception of sovereign risk. Future flow securitization is a foul-weather friend for investment grade entities in below investment grade countries.

2. Securitization transactions can be very costly to an issuer, because such transactions are relatively new and (so far) less amenable to standardization. Fees for obtaining investment banking expertise, legal services and credit rating can be very high, and preparation times very long in undertaking a future flow securitization deal.

3. However, such transactions can be structured to mitigate sovereign risk so that a developing country borrower can access longer-term financing at lower interest rates than unsecured bonds. Typically such benefits of lower interest rates or longer maturity far outweigh the high fixed costs of undertaking future flow securitization, especially during a crisis.

4. The size of future receivables of developing countries that are suitable for securitization is much larger than (more than ten times) the current level of issuance at under $\$ 10$ billion annually. Of these receivables, a large part comes from outside Latin America, especially from countries in Eastern Europe and Central Asia that are rich in fuel and mineral exports. Countries in the Middle-East have large oil

\footnotetext{
${ }^{3}$ Developing country entities include companies (both private and public) as well as sovereign and subsovereign bodies.

${ }^{4}$ See Appendix A for some examples of future flow securitizations. Such structures enable securitization of several years worth (or a multiple) of export receivables. In contrast, trade finance---an example of existing asset securitization--- typically brings in 90-day financing and hence the amounts that can be raised via this mechanism are one-fourth of a year's export receivables.
} 
receivables. In South Asia, the potential for securitization lies in remittances, credit card vouchers, and telephone receivables.

5. A major constraint to the growth of future flow transactions arises from the paucity of good collateral in developing countries. Oil is an example of a good collateral for several reasons: a) the stock of oil in a country is more or less well-known; b) this is a highly 'liquid' asset with well-developed global markets, c) it is usually of great importance to a nation's economy and, therefore, its exports are less vulnerable to government interference. Finally, crude oil may be a better collateral than refined petroleum because the former cannot be easily diverted to foreign importers (obligors) not included in the securitized structure. In comparison, agricultural commodities tend to be more difficult to securitize, although the number of such deals has risen rapidly in recent years.

6. The paucity of good collateral is also reflected in the absence of high-quality public and private issuers in developing countries. Securitization deals tend to be complex and involve high preparation costs and long lead-times. The lack of legal clarity on bankruptcy procedures in many developing countries adds further complexity to these deals. In some cases, policy makers are simply not familiar with this mechanism. Many issuers are constrained by the burden of full disclosure of information in a timely fashion. Others worry about whether the use of future flow secured bonds will taint their creditworthiness.

7. Public policy to facilitate future flow-backed securitizations should focus on removing these constraints. Transaction costs may be reduced through expansion of the scale of these deals by planning a series of deals by the same issuer (the so-called master trust arrangement). Establishment and use of indigenous credit rating agencies to obtain domestic credit rating can also reduce transaction costs, although care has to be taken in mapping local rating scales to international scales. Certain segments of this asset class - such as securitization of oil receivables - may be amenable to standardization and a cookie-cutter approach. Clarification of bankruptcy laws will be helpful for all financial deals including securitization. Also, educating policy makers and potential issuers would help promote this asset class.

8. However, future flow securitization increases the level of inflexible debt of an issuer at the micro level, and of the nation at the macro level. Although the current level of future flow debt is nowhere near the danger level in any country, such debt combined with debt from other preferred creditors can reduce the flexibility and the ability to service the non-preferred debt.

9. Governments may find this asset class attractive because, when planned and executed ahead of time, it can provide a way of accessing markets during times of liquidity crisis. There are also significant externalities associated with future flow deals. By clarifying the legal and institutional environment surrounding a developing country issuer, such deals can pave the way for future deals by other issuers as well. Because of their investment grade rating, future flow deals attract a much wider class of 
investors than unsecured deals. Thus, future flow deals can improve market liquidity and reduce market volatility. That can generate added interest on the part of international investors in other asset classes or other borrowers.

I.7 The plan of this paper is as follows. In section II we describe a typical structure of a future flow-backed securitization that mitigates the most common elements of sovereign risk, thereby permitting a credit rating above the sovereign ceiling. In this section, we also examine the ratings implications of any residual risks that cannot be structured away. In section III, we examine principal characteristics of future flow securitizations by developing country entities that were rated by Fitch IBCA, Duff \& Phelps (Fitch), Moodys and Standard \& Poor's (S\&P). The rationale for securitization is discussed in section IV. We estimate the potential size of this asset class in section V, and outline various constraints that have prevented the asset class from reaching its potential in section VI. Finally, in section VII we take up a number of public policy issues relevant to facilitating future flow securitization in the years to come.

\section{Risk Mitigation in Securitized Transactions}

II.1 International future flow securitizations are structured debt offerings sponsored by a foreign originator and secured by receivables due from designated international obligors. A typical future flow structure is set out in Chart 1. It involves the originating entity in a developing country selling its future product (receivable) directly or indirectly to an offshore Special Purpose Vehicle (SPV). The SPV issues the debt instrument. Designated international customers are directed to pay for the product from the originating entity directly to an offshore collection account managed by a trustee. The collection agent makes principal and interest payments to the investors. Excess collections from obligors are directed to the originator via the SPV. (Two examples of future flow securitization structures are provided in the appendix.)

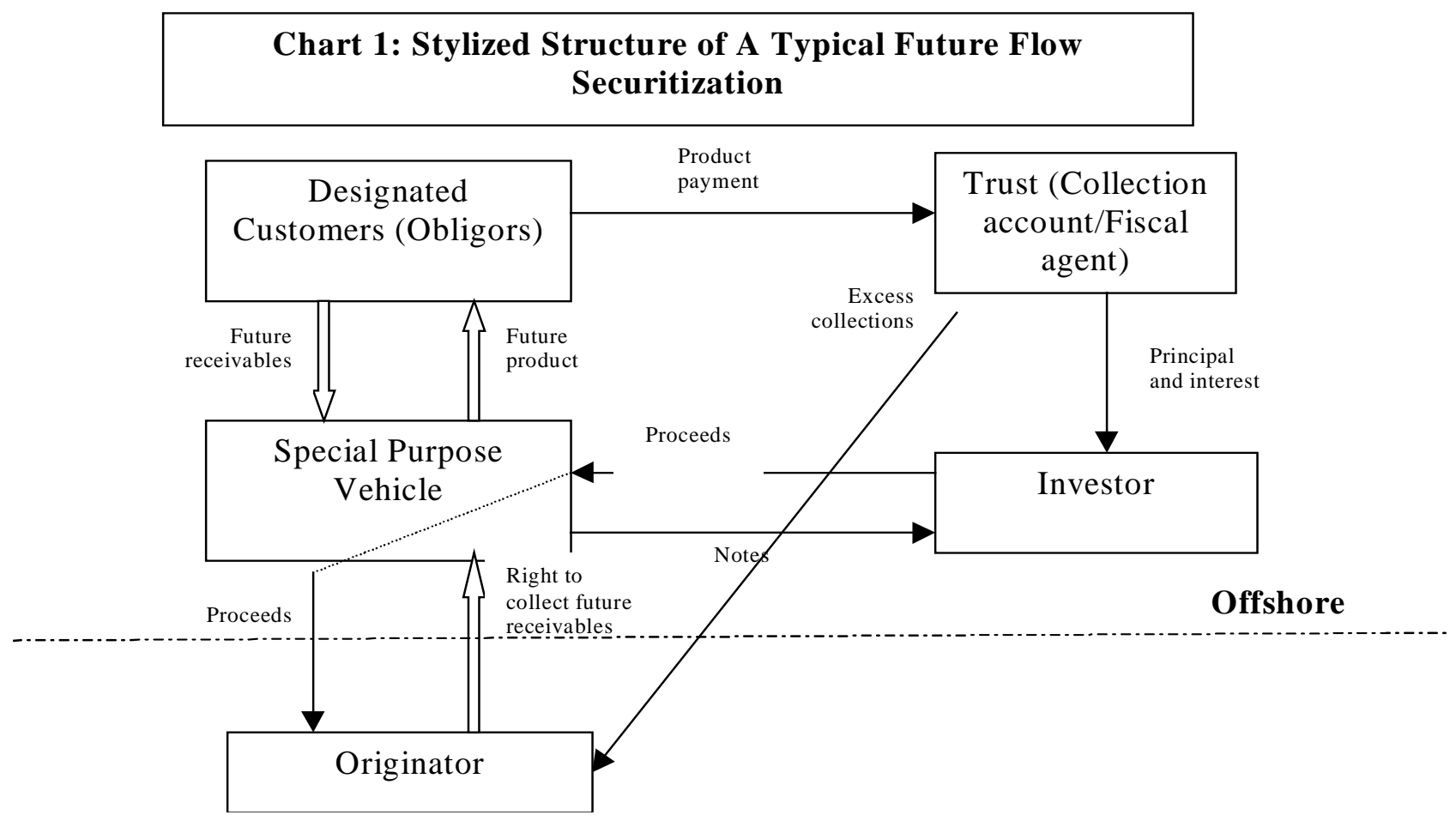


II.2 Risk mitigation in securitized transactions occurs via the structure of the transaction as well as the choice of the future flow receivable to be securitized. ${ }^{5}$ Since payments on the receivables do not enter the issuer's home country, the rating agencies believe that the structure mitigates the usual sovereign transfer and convertibility risks (see Box 1 for an explanation of various types of risks). The structure described above also mitigates the bankruptcy risk because the SPV has typically no other creditors and hence cannot go bankrupt. Of course, the risk of the originator going bankrupt exists. Such risk is mitigated in part by seeking originators with high local currency (domestic) credit ratings. Furthermore, legal experts in many developing countries have opined that creditors will continue to have access to the pledged security even after a bankruptcy petition is filed. ${ }^{6}$

\section{Box 1: Various Types of Risks Involved in Future Flow Securitization}

Sovereign risk: will the originator's government take steps to disrupt the payment arrangement set out in the structured transaction?

Performance risk: will the originator have the ability and willingness to produce and deliver the product?

Product risk: will there be sufficient demand for the product at a stable price and will the buyer meet his payment obligations?

Diversion risk: can the product or the receivable be diverted to customers other than designated customers.

Additionally, there are currency devaluation risk, bankruptcy risk and political risk, which are related to sovereign risk. The usual transfer and convertibility risks are substantially mitigated when hard currency future flow receivables are securitized via an SPV structure. (For a detailed discussion of various types of risks and how these can be mitigated through structuring, see Duff \& Phelps (1999a) and Standard \& Poor's Structured Finance: Emerging Markets Criteria.)

II.3 However, a number of residual risks such as performance risk, product risk and sovereign risk remain and they are difficult to structure away.

II.4 Performance Risk: The ability and willingness of the originator to produce and deliver the product is generally captured in the issuer's local currency rating. But for certain entities such as banks, Fitch uses the going concern and S\&P the "survival" assessment of the originating entity in rating an asset-backed transaction higher than the issuer's local currency rating. This reflects the belief that in many countries financial

\footnotetext{
${ }^{5}$ This section draws from two rating agency publication, in particular S \& P's "Lessons from the Past Apply to Future Securitizations in Emerging Markets" and Duff and Phelp's "Methodology for Rating Future-Flow Securitization".

6 Section 552 of the U.S. Bankruptcy Code does not give creditors access to the security (such as FF receivables) once a bankruptcy petition is filed. Hence, there have been no FF-backed transactions in the United States. Legal provisions in many developing countries are ambiguous enough, however, to permit the so-called "true sale" opinion.
} 
default does not lead to liquidation of an entity. ${ }^{7}$ In other words, an entity may continue to generate receivables (that are captured by the offshore trust) even when it is in financial default. This is particularly applicable to sovereign or sub-sovereign entities and public sector companies.

II.5 Product Risk: A number of factors can reduce the product risk. For instance, the product risk will be lower if there is either a stable or an increasing demand for the product. If the issuer has a competitive cost advantage, that would be an additional plus. Finally, it is also helpful if a long-term purchasing contract from a reputable buyer underpins the demand.

II.5.1 Price volatility and seasonal fluctuations in cash flow are other distinctive features of the product risk. This risk is typically mitigated by over-collateralization or excess coverage. While excess coverage helps mitigate elements of product risk, it also reduces the total amount of funds that can be raised with future flow receivables.

II.5.2 Typically, commodities like oil, gas, metals and minerals are thought to be ideal to control product risk because the demand for these comes from many diverse sources. In contrast, custom-made products are likely to have high product risk unless there are adequately enforceable long-term sales contracts. ${ }^{8}$ Homogeneous commodity exports have dominated this asset class with oil and gas export receivables accounting for 46 percent of total issuance since 1987. Minerals and metals including aluminum, copper, iron ore pellets, gold and silver and agricultural commodities like coffee, orange juice concentrate, pulp and paper, and soy have also figured in the issuance of future flow receivable-backed securities. Other major receivables that have been securitized include credit card vouchers, net telephone settlement receivables, airline tickets and remittances.

II.5.3 Yet another product risk comes into play via the credit rating of the entity which has undertaken the commitment to purchase the product and generate the receivable. The purchasing company's credit rating together with the rating on its sovereign becomes an important consideration. ${ }^{9}$ This risk can be mitigated to the extent the originator has a sales contract with a highly rated company in a highly rated country.

II.6 Sovereign Risk: While a securitized transaction can be structured so as to minimize the transfer and convertibility sovereign risks, some other elements of sovereign risk cannot be totally eliminated. ${ }^{10}$ In extreme situations, the sovereign after all has the ability to do a variety of things to disrupt the flow of the product to the market and the generation of the receivable. For instance, the sovereign can insist upon the

\footnotetext{
${ }^{7}$ See Fitch (2000a, 2000b) and Standard \& Poor's (2000).

${ }^{8}$ However, homogeneous commodities may be vulnerable to diversion or re-direction risk, and therefore, less suitable for a future flow transaction.

${ }^{9}$ The credit rating of the entity undertaking to purchase the product is much less of an issue in the case of a true commodity since only short-term credit risk (between the time the product is shipped and the time payment is received) needs to be covered.

${ }^{10}$ The degree of sovereign risk mitigation varies depending on the nature of the transaction, but it is impossible to eliminate sovereign risk. See Standard and Poor's Structured Finance -- Emerging Markets Criteria.
} 
originator selling the product in the domestic market rather than in the export market. This product diversion risk is generally greater for commodities that are in high demand at home. Little wonder that agricultural staples have not figured much in future flow receivable structured finance deals.

II.6.1 Furthermore, the sovereign can also compel obligors to pay directly to the Central Bank instead of the Trust. To guard against this risk, future flow transactions make designated customers (obligors) sign a Notice and Acknowledgement, binding under the U.S. law (or the law of a highly rated country), that they will make payments to the offshore trust. Consequently, the sovereign is unlikely to take such a step lightly. Note that if only a small percent of the receivable amount is needed to service the debt while the majority returns to the originator, the sovereign is unlikely to risk litigation from investors that potentially disrupts trade flows. This consideration also leads to excess coverage or over-collateralization.

II.6.2 Currency devaluation is yet another element of sovereign risk that cannot be totally eliminated even in structured transactions. For instance, currency devaluation may reduce credit card receivable amounts unless the tourism volumes happen to be sufficiently elastic.

II.7 Keeping in mind the performance, product and sovereign risks, the rating agencies have arrived at the following hierarchy of future flow receivable transactions in terms of deals that are most secure to those that are least secure. The securitization of heavy crude oil receivables is deemed to be most secure while the securitization of future tax receipts is thought to be least secure.

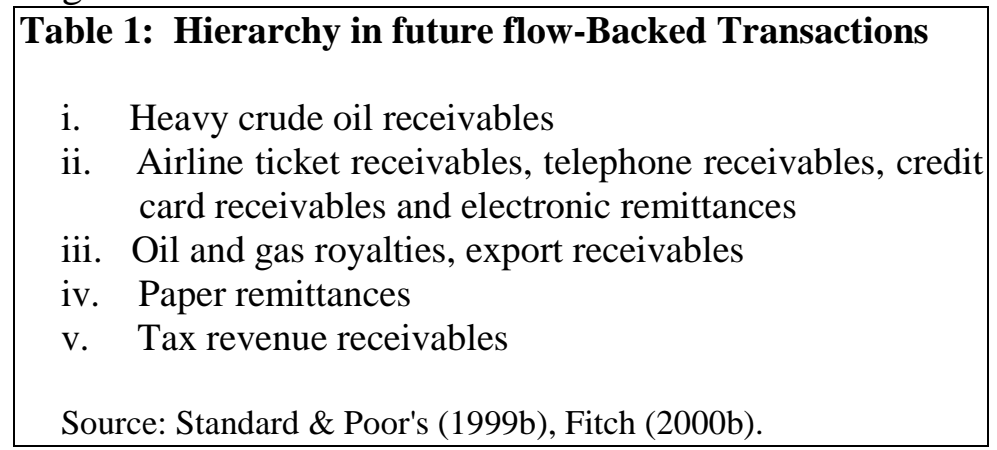

II.8 It is possible to securitize future flow receivable transactions even at the lowest end of the hierarchy shown in Table 1. An example of this is the securitization of coparticipation tax revenues (via federal tax sharing) by several Argentine provinces (Standard \& Poor's 1999). Of course, it becomes more difficult to obtain investment grade transaction rating as one moves to the lower end of the hierarchy. Alternatively, it becomes necessary to build in more safeguards to improve credit rating as one moves down the hierarchy. ${ }^{11}$

\footnotetext{
${ }^{11}$ The ability to structure away sovereign risks is greatly reduced at the height of a liquidity crisis. The risk mitigation through future flows structure works best when sovereign risk perception are high and liquidity is low, but not during a full-blown crisis.
} 
II.9 Insurance companies are playing a rising role in the 1990s insuring the various elements of risk described in Box 1. A number of insurance companies have provided complete financial guarantee as MBIA did for the recent Pemex Finance Ltd. securitization. (The Pemex Finance structure is presented in the appendix.)

\section{Salient Characteristics of Securitized future flow transactions}

III.1 Securitization of existing assets and future flow receivables has a relatively short history in developing countries. The first important future flow securitized transaction in a developing country occurred in 1987 with the securitization of telephone receivables due to Mexico's Telmex. Since then the three principal rating agencies---Fitch IBCA, Duff and Phelps (Fitch), Moodys and Standard \& Poors (S\&P)---have collectively rated well over 200 securitizations with the aggregate principal amount totaling US\$47.3 billion. The issuance peaked in 1997 at 46 transactions (See Chart 2).

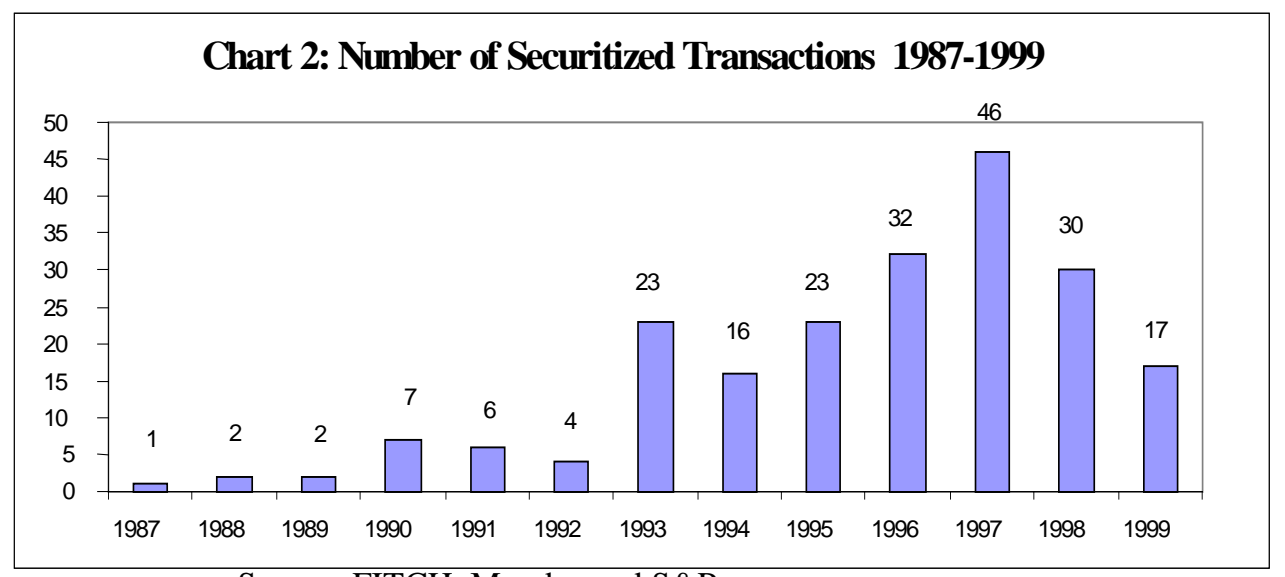

Source: FITCH, Moodys and S\&P.

III.2 The securitization of future flow receivables as a financing mechanism has increased after the Mexican peso crisis in 1994-95 as sovereign ratings were downgraded and borrowing costs rose in major Latin American countries (Chart 3).

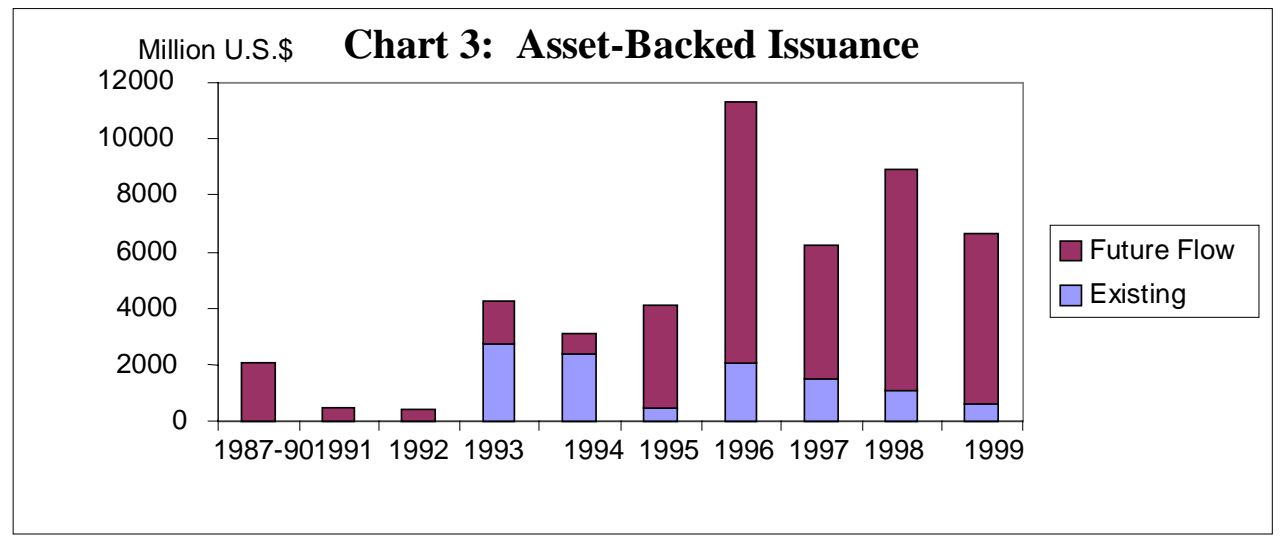

III.3 A predominant 77 percent of securitization transactions (in nominal dollar term) during 1987-1999 involved future-flow receivables. Amounts raised via securitization of existing assets have been relatively small at US\$10.9 billion as opposed to US\$36.4 billion raised via future flow receivables (Chart 4). 


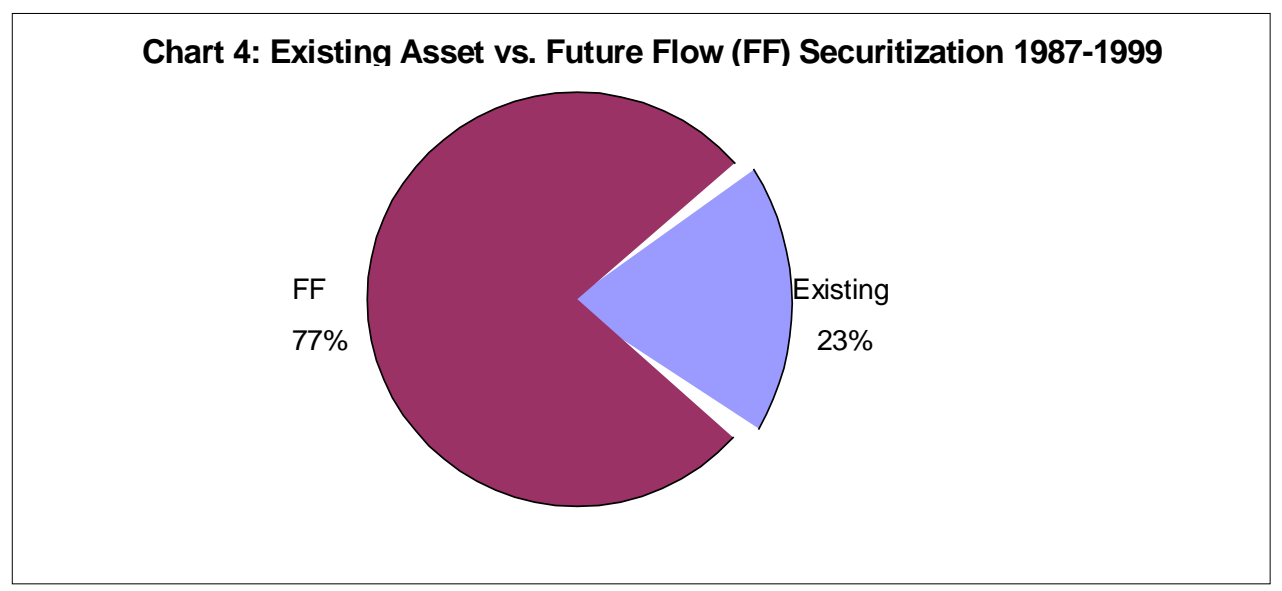

Source: FITCH, Moodys and S\&P

III.4 As Table 2 shows, large Latin American issuers have dominated the market in terms of both the number of issues and the amount of issuance. Mexico alone accounts for over one-half of asset-backed transactions in dollar terms; Brazil and Argentina account for another 34 percent. The dominant of these countries in this asset class is perhaps due to their more developed and deeper domestic capital markets (relative to other developing countries). Also these countries have long and well-established relationship with international investors.

Table 2: Asset-Backed Issuance 1987-1999

\begin{tabular}{|c|c|c|c|c|}
\hline \multirow{2}{*}{$\begin{array}{l}\text { (as of June 2000) } \\
\text { Country }\end{array}$} & \multicolumn{2}{|c|}{ Future Flow Asset } & \multicolumn{2}{|c|}{ Existing Asset } \\
\hline & Billion US\$ & Percent & Billion US\$ & Percent \\
\hline Argentina & 3.2 & 8.7 & 2.1 & 20 \\
\hline Brazil & 3.3 & 8.8 & 0.2 & 2 \\
\hline Chile & 0.2 & 0.4 & 0.0 & 0 \\
\hline Colombia & 1.5 & 4.0 & 0.0 & 0 \\
\hline Costa Rica & 0.1 & 0.2 & 0.0 & 0 \\
\hline Dom. Rep. & 0.0 & 0.1 & 0.0 & 0 \\
\hline El Salvador & 0.1 & 0.4 & 0.0 & 0 \\
\hline Guatemala & 0.1 & 0.2 & 0.0 & 0 \\
\hline Honduras & 0.0 & 0.0 & 0.0 & 0 \\
\hline Indonesia & 0.2 & 0.4 & 0.2 & 2 \\
\hline Jamaica & 0.1 & 0.4 & 0.0 & 0 \\
\hline Mexico & 18.8 & 52.2 & 5.8 & 53 \\
\hline Nigeria & 0.3 & 0.8 & 0.0 & 0 \\
\hline Pakistan & 0.3 & 0.7 & 0.0 & 0 \\
\hline Panama & 0.3 & 0.8 & 0.0 & 0 \\
\hline Peru & 0.6 & 1.5 & 0.0 & 0 \\
\hline Turkey & 1.3 & 3.5 & 0.2 & 2 \\
\hline Venezuela & 6.1 & 16.4 & 0.0 & 0 \\
\hline Hong Kong & 0.0 & 0.0 & 0.2 & 2 \\
\hline Asia & 0.0 & 0.0 & 0.0 & 0 \\
\hline Other & 0.2 & 0.5 & 2.2 & 20 \\
\hline Total & 36.4 & 100.0 & 10.9 & 100 \\
\hline
\end{tabular}

Source: FITCH, Moodys and S\&P 
III.5 Nearly one-half of all rated securitizations are backed by oil and gas export receivables (table 3). Oil is a relatively good collateral for future flow securitizaztion for several reasons: a) the stock of oil in a country is more or less well-known; b) this is a highly 'liquid' asset with well-developed global markets, c) it is usually of great importance to a nation's economy and, therefore, its exports are less vulnerable to government interference. Finally, crude oil may be a better collateral than refined petroleum because the former cannot be easily diverted to foreign importers (obligors) not covered the securitization structure. In contrast, agricultural commodities may be more difficult to securitize. ${ }^{12}$

III.6 Nevertheless, this asset class has shown enormous creativity. Non-oil export receivables (e.g., iron, copper, aluminum, coffee, soy and orange juice) support 18 percent of future flow transactions during 1987-99. Credit card receivables, project finance,$^{13}$ telephone receivables, remittances and tax receivables account for most of the remaining transactions. Since these non-oil deals tend to be smaller than oil transactions, their share in dollar terms tends to underestimate their significance in terms of number of transactions. Thus, while oil and gas related transactions accounted for 46 percent of transactions by dollar amount, they comprised less than 12 percent of all future flow transactions completed to date (table 3).

Table 3: Future flow securitization by sector

\begin{tabular}{lccc}
\hline & \$ million & $\begin{array}{c}\text { Share of total } \\
\text { dollar volume } \\
(\%)\end{array}$ & $\begin{array}{c}\text { No. of } \\
\text { transactions }\end{array}$ \\
\hline Oil \& gas export receivables & 16,362 & 45.0 & 25 \\
Non-oil export receivables & 7,537 & 20.7 & 40 \\
Credit card receivables & 4,314 & 11.8 & 37 \\
Project finance & 2,467 & 6.8 & 6 \\
Telephone receivables & 2,519 & 6.9 & 15 \\
Remittances & 1,731 & 4.8 & 14 \\
Other receivables & 1,443 & 4.0 & 11 \\
& 36,372 & 100 & 148 \\
\hline
\end{tabular}

Source: Fitch, Moodys and S\&P

\footnotetext{
${ }^{12}$ Another aspect of the choice of collateral for securitization is the covariance of the value of receivables and the economic cycle of a country. If the covariance is high and the value of collateral declines in times of crisis, this collateral is less useful as a means of raising finance during a crisis. In fact, such covariance may be asymmetric in the sense that the loss of value during a crisis may be higher than the gain in value during a comparable boom phase (Izquierdo 2000). However, the "pro-cyclicality" may depend upon many factors including the nature of the crisis. If, for example, the crisis is due to a terms-of-trade shock, export receivables will lose value; if, on the other hand, the crisis leads to a currency devaluation, the value of export receivables will rise or fall depending upon the elasticity of demand.

${ }^{13}$ Project finance transactions securitize receivables to be generated by developing new investment projects such as the exploitation of the extra heavy oil in Venezuela.
} 


\section{Rationale for Securitization}

IV.1 Future flow securitization transactions are appealing to issuers because they reduce the cost of raising finance, particularly in times of distress in global capital markets. These are also attractive for investors-especially "buy-and-hold" investors such as insurance companies-because of their investment grade rating, and their impeccable performance record in good times as well as bad. These transactions also carry significant implications for domestic capital market development, providing an additional incentive (besides market access during crisis) for governments to promote this asset class.

IV.2 Asset-backed securities offer significant cost savings to issuers by enabling them to pierce the sovereign credit ceilings via appropriate risk mitigation. The extent of cost saving inevitably depends upon conditions in the international capital markets. This is evident from the example of Pemex, a state enterprise of Mexico and one of the largest oil and gas companies in the world.

IV.3 Following the Mexican peso crisis in December 1994, the spread on the emerging market bonds (represented in J P Morgan's EMBI+ index) soared to 1555 bp in March 1995 from around 844 bp in November 1994. In early 1995, the Government of Mexico began the process of issuing floating rate notes backed by oil exports. These securities, which were subsequently issued in August 1996, received BBB- ratings from FITCH and S\&P - two notches higher than Mexico's sovereign rating of BB. In late 1998, Pemex Finance Ltd. issued a series of oil export backed securities which received FITCH and S\&P credit ratings of AAA and BBB, as shown in Table 4 below, and were sold to investors at spreads over U.S. Treasuries ranging from $125 \mathrm{bp}$ to $412.5 \mathrm{bp}$. The spread on the unsecured Pemex debt at the time was 462.5 bp and that on United Mexican States (UMS) debt of roughly equal maturity was $571 \mathrm{bp}$. Thus, Pemex saved via securitization anywhere from 50 basis points to 337.5 basis points from what it would have had to pay on senior Pemex debt. The saving relative to UMS spread was even more substantial.

Table 4: Spreads on Pemex Finance Ltd. Securitized Debt

\begin{tabular}{lccccccc}
\hline & Rating** & $\begin{array}{c}\text { Issue Size } \\
\text { Million } \\
\text { US\$ }\end{array}$ & $\begin{array}{c}\text { Average } \\
\text { Life }(\mathrm{yrs})\end{array}$ & $\begin{array}{c}\text { Final } \\
\text { Life }(\mathrm{yrs})\end{array}$ & $\begin{array}{c}\text { Spread } \\
(\mathrm{bp})\end{array}$ & $\begin{array}{c}\text { Coupon } \\
(\%)\end{array}$ & $\begin{array}{c}\text { Issue } \\
\text { Date }\end{array}$ \\
\hline Pemex Finance A & AAA & 500 & 3 & 5 & 125 & 5.720 & $12 / 4 / 98$ \\
Pemex Finance A & BBB & 350 & 7 & 8.5 & 350 & 7.000 & $12 / 4 / 98$ \\
Pemex Finance A & AAA & 400 & 10 & 11.5 & 175 & 6.300 & $12 / 4 / 98$ \\
Pemex Finance A & BBB & 250 & 18 & 20 & 412.5 & 9.150 & $12 / 4 / 98$ \\
Pemex Sr. Unsecured & BB & 600 & & 10 & 462.5 & 9.375 & $12 / 2 / 98$ \\
UMS* & BB & 1500 & & 10 & 571 & 9.875 & $12 / 4 / 98$ \\
\hline
\end{tabular}

** Tranches rated AAA had bond insurance.

* UMS 2007 debt issued in 1997 when UMS had a rating of BB. The spread from the yield on 30-year U.S. Treasury bond maturing in 2007.

Source: S\&P

IV.4 A recent future flow secured issuance by Pemex Finance yielded only a $50 \mathrm{bp}$ cost saving to the issuer. The early February 2000 issue of Pemex Finance's structured debt 
was placed at a spread of 275 bp when the spread on the unsecured Pemex debt was 325 bp. This issuance by Pemex was part of an existing master trust arrangement. Pemex proceeded with this issuance because the structure was already in place; but perhaps it also wanted to keep the door open to future securitized financing if times were to turn hard. Note that even a 50 basis point saving on spread can be significant due to compounding effects. ${ }^{14}$ This example also shows that future flow receivable-backed transactions offer most spread advantage to issuers in bad rather than good times in the international capital markets. In other words, asset-backed finance can be a foul-weather friend for issuers in developing countries.

IV.5 The Mexican crisis of 1994-95 also produced an adverse impact on Argentina's ability to raise finance in a cost-effective way. Consequently, Argentina's oil company YPF (by then privatized) resorted to asset-backed financing by issuing $\$ 400$ million at a 200 basis point spread advantage.

IV.6 In addition to providing lower cost funding, securitization also allows issuers to extend maturity of their debt, and improve risk management as well as balance sheet performance (e.g., return on equity). Securitization also permits issuers from developing countries to tap a wider class of investors. For example, this asset class is attractive to insurance companies who are required to buy only investment-grade assets. These investors also tend to "buy and hold" an asset until maturity. Moreover, by establishing a credit history for the borrower, these deals enhance the ability and reduce the costs of accessing the market in future.

IV.7 Most of these incentives are common to public and private sector entities. However, private sector issuers are unlikely to undertake issuance---future flow or otherwise---during times of crisis. Thus, using future flow transactions to raise financing during a crisis is possible only in the case of public sector entities. However, considering the long lead times involved in future flow deals, even public sector entities would be well advised to keep securitization deals in the pipeline and investors engaged even in good times so that the asset class remains accessible during a crisis (more on this later).

IV.8 From the investors' point of view, the attractiveness of future flow securities lies in their good credit rating and their performance in good as well as bad times. Since much of secured debt paper is traded infrequently, there is a lack of adequate information on secondary market price and spread on securitized debt. Nevertheless, available information (as well as the perception of market players) suggests that future flow securities tend to be less volatile in price and spread than unsecured debt from developing countries. A comparison of spreads on the 7-year and 18-year future oil export receivable backed Pemex securities against the spread on United Mexican States (UMS) unsecured bench-mark eurobond maturing in 2026 is presented in Charts 6a and 6b for the period from January 29, 1999 through April 21, 2000. These charts show that spreads on securitized Pemex debt are in general lower than those on UMS 2026, although some times (e.g., the fourth quarter of 1999) this relationship actually reversed as the price of

\footnotetext{
${ }^{14}$ For example, a 100 basis point spread saving translates into roughly $\$ 5$ million interest saving after 4 years on a $\$ 100$ million loan.
} 
UMS eurobond became more volatile (Chart $6 \mathrm{~b}$ ). Table 5 also indicates that the assetbacked Pemex papers had lower average spread and lower standard deviation of spreads than the UMS 2026. Furthermore, regressions ${ }^{15}$ of Pemex 7-year and 18-year spreads on UMS 2026 spreads yield slope coefficients of 0.62 and 0.68 respectively, implying that a one basis point change in the spread on UMS 2026 was associated with a smaller change in the spread on Pemex asset backed securities.
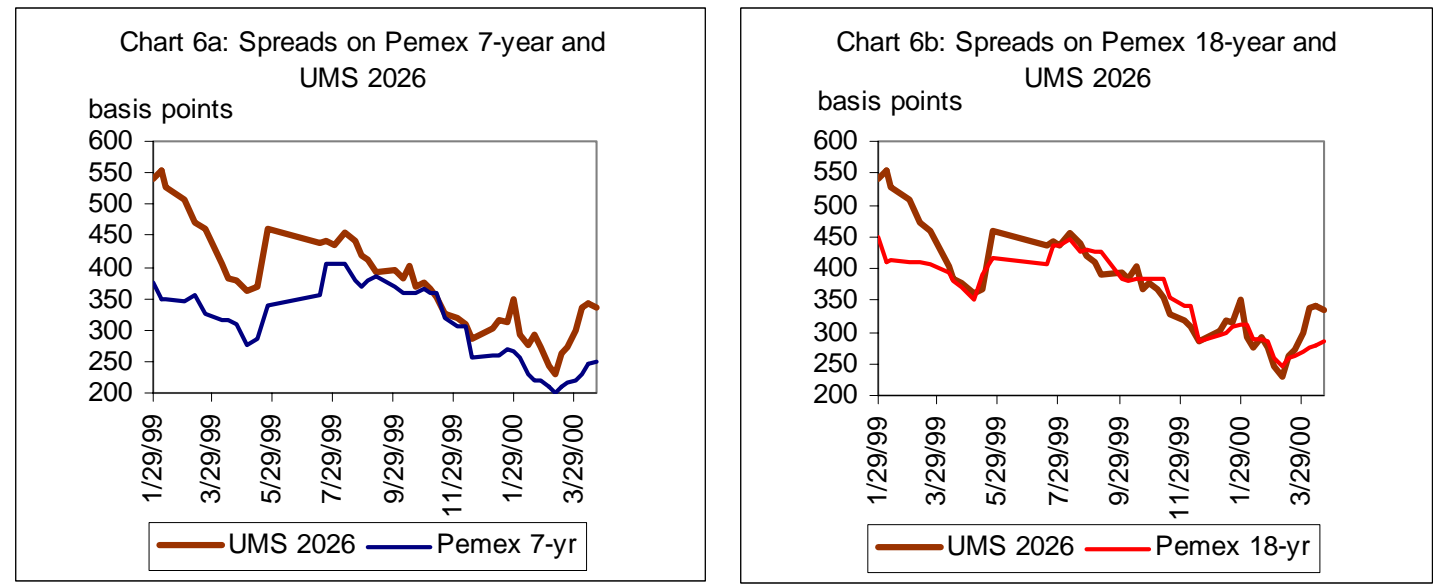

Source: JPMorgan and Bloomberg

Table 4: Statistical Characteristics of Pemex 7-year and 18-year asset-backed papers and UMS 2026 (unsecured)

\begin{tabular}{cccc}
\hline & Pemex 7-year & Pemex 18-year & UMS 2026 \\
\hline Mean & 309 & 356 & 372 \\
Range & 205 & 202 & 324 \\
Standard deviation & 63 & 62 & 79 \\
\hline
\end{tabular}

Source: JPMorgan and Bloomberg

IV.9 There have been no debt defaults on rated future flow asset-backed securities issued by developing country entities despite repeated crises of liquidity and/or solvency (Fitch 1999c). Thus, the asset class has withstood the test of the Mexican peso crisis in 1994-95, the Asian liquidity crisis in 1997-98, and the Russian and Ecuadorian debt defaults in 1998 and 1999. An interesting example is the Pakistan telephone receivable deal that continued to perform even in the face of selective default on sovereign debt (see Box 2).

\footnotetext{
${ }^{15}$ These are linear regressions with a constant term. The slope coefficients are significant at 1 percent level and the adjusted R-squares are 0.61 and 0.75 respectively for Pemex 7-year and 18-year asset backed papers.
} 


\section{Box 2: Pakistan Telecommunications Company Limited (PTCL) No default on asset-backed papers even in the face of selective default on sovereign debt}

In 1997, the Pakistan Telecommunications Company Limited (PTCL) issued $\$ 250$ million in bonds backed by future telephone settlement receivables from AT\&T, MCI, Sprint, British Telecom, Mercury Telecommunications and Deutsche Telekom. Even though PTCL is owned 88 percent by the Government of Pakistan, this issue was rated BBB- by S\&P, four notches higher than the B+ sovereign rating.

Following the detonation of nuclear devices in May 1998, Pakistan's economy and creditworthiness deteriorated rapidly. Investors became concerned that faced with increasing official demands for equal burden sharing, the government might place the future flow receivable-backed securities in a single basket with all other sovereign debt and interfere with PTCL's debt servicing. The Government of Pakistan rescheduled its Paris Club debt obligations on January 30, 1999 and signed a preliminary London Club agreement on July 6, 1999 to reschedule $\$ 877$ million of sovereign commercial loan arrears. But PTCL's future flow net receivable backed bonds were not subjected to any rescheduling or restructuring, although their rating was downgraded several times during 1997-98 (see table below). Partly this was because the amount required to service these obligations made up only 30 percent of the total net telephone receivables of the company. But the main reason was that there was a strong incentive on the sovereign's part to keep servicing the bonds and not jeopardize the operation of the local telephone network and even more importantly risk severing Pakistan's telecommunication link to the rest of the world.

\section{History Of PTCL Credit Rating}

\begin{tabular}{|c|c|c|c|}
\hline Date & $\begin{array}{l}\text { Pakistan } \\
\text { Sovereign } \\
\text { Rating }\end{array}$ & PTCL Rating & Comment \\
\hline Aug-97 & $\mathrm{B}+$ & BBB- & At issuance due to its structure \\
\hline Jun-98 & B- & $\begin{array}{l}\mathrm{BB}+/ \mathrm{Neg} \text {. } \\
\text { outlook }\end{array}$ & $\begin{array}{l}\text { Following the detonation of a nuclear device } \\
\text { which led to the imposition of trade sanctions and } \\
\text { the freezing of } \$ 13 \text { billion in foreign currency } \\
\text { bank deposits }\end{array}$ \\
\hline Jul-98 & $\mathrm{CCC}$ & B- & $\begin{array}{l}\text { Following a downgrade of Pakistan's rating from } \\
\text { B- to CCC }\end{array}$ \\
\hline Dec-98 & $\mathrm{CC}$ & $\mathrm{CCC}+$ & $\begin{array}{l}\text { Following a tentative agreement with the IMF } \\
\text { which opened the way for debt restructuring while } \\
\text { leaving uncertain the precise fate of PTCL debt }\end{array}$ \\
\hline Jan-99 & SD & $\mathrm{CCC}+$ & $\begin{array}{l}\text { Following the rescheduling of US } \$ 969 \text { million of } \\
\text { commercial loans in default since July } 1998 .\end{array}$ \\
\hline Dec-99 & B- & $\mathrm{CCC}+$ & Expected to be upgraded to BB \\
\hline
\end{tabular}

IV.10 While this track record (of no default) is encouraging for this asset class, the test has not been severely stringent until now because future flow asset-backed debt still represents a very small percentage of total debt. ${ }^{16}$

\footnotetext{
${ }^{16}$ So far, given the small size of future flow issuance, the pledging of future assets has not affected the cost or the rating of unsecured debt. But obviously there are limits to the amount of future exports that can be pledged for such purposes.
} 
IV.11 Governments may find this asset class attractive because, if planned and executed ahead of time, it can provide a way of accessing markets during times of liquidity crisis. Because of their investment grade rating, future flow deals attract a much wider class of investors than unsecured deals. Thus, future flow deals can improve market liquidity and reduce market volatility. That can generate added interest on the part of international investors in other asset classes or other borrowers. For many developing countries, future flow receivable-backed securitization may be the only way to begin accessing international capital markets. ${ }^{17}$

IV.12 But perhaps the most important incentive for governments to promote this asset class lies in the externalities associated with future flow deals. Future flow deals involve a much closer scrutiny of the legal and institutional environment---the existence as well as the implementation of laws relating to property rights and bankruptcy procedures--than unsecured transactions. In trying to structure away various elements of sovereign risk, highly trained professionals from investment banks, legal firms, and international rating agencies spend enormous amounts of time and energy examining the investment climate in a country paying special attention to ways in which the sovereign can affect the performance of a private (or public) sector entity. They also closely study the risks facing the sovereign itself. Thus, these deals can produce enormous informational externalities by clarifying the legal and institutional environment and the investment climate in a developing country. Besides, the preparation of a future flow transaction if backed by the government may involve structural reforms of the legal and institutional environment. These reforms would facilitate domestic capital market development and encourage international placements as in the aftermath of the Brady deals in the early 1990s.

\section{Potential for Future Flow Receivable Securitization}

V.1 The future flow secured transactions allow issuers to pledge receivables over a number of years and hence open up the possibility of raising funds in capital markets that are a multiple of a given year's receivables. Based on the discussions in sections II and III, this section provides an estimate of the receivables from exports of fuels, minerals and agricultural raw materials, credit card vouchers, worker remittances and telephone receivables of developing countries that are suitable for future flow securitization. The objective of this exercise is not to forecast, but to obtain a benchmark against which constraints on such issuance can be compared.

V.2 Fuel exports of low and middle-income countries in 1998 totaled $\$ 196$ billion, mineral exports amounted to $\$ 63$ billion, and exports of agricultural raw materials reached $\$ 30$ billion. Using a conservative 5:1 over-collateralization ratio implies that the size of future export receivables that can be securitized, based on 1998 exports data, is

\footnotetext{
${ }^{17}$ International capital flows are a way of smoothing adjustments to shocks. In a developing country, the link with international capital markets tends to be weak, and also the domestic capital market tends to be underdeveloped. Both these weaknesses limit the role of international capital in smoothing adjustment to shocks (Caballero 2000).
} 
as high as $\$ 289$ billion over a three-year period or nearly $\$ 58$ billion per year. Even leaving out agricultural raw materials, the securitizable exports will still remain over $\$ 50$ billion per year in 1998 prices (table 5).

Table 5: Securutization Potential by Region, 1998 (US\$ billion)

\begin{tabular}{|c|c|c|c|c|c|}
\hline & $\begin{array}{c}\text { Fuels } \\
\text { (1) }\end{array}$ & $\begin{array}{c}\text { Minerals } \\
\text { (2) }\end{array}$ & $\begin{array}{c}\text { Agr. Raw } \\
\text { Materials. } \\
\text { (3) }\end{array}$ & $\begin{array}{c}\text { Remittances } \\
\text { (4) }\end{array}$ & $\begin{array}{c}\text { Region } \\
\text { total } \\
(1)+(2)+(3 \\
+(4))\end{array}$ \\
\hline East Asia & 5.3 & 2.1 & 2.1 & 0.1 & 9.7 \\
\hline Europe and Central Asia & 9.8 & 4.6 & 1.5 & 0.7 & 16.7 \\
\hline Latin America \& Caribbean & 7.5 & 5.2 & 1.7 & 1.3 & 15.8 \\
\hline Middle East \& North Africa & 16.5 & 0.4 & 0.2 & 1.0 & 18.1 \\
\hline South Asia & 0.1 & 0.2 & 0.2 & 1.4 & 1.9 \\
\hline Sub-Saharan Africa & n.a & n.a & n.a & 0.2 & n.a \\
\hline $\begin{array}{l}\text { Low and Middle-Income } \\
\text { Countries }\end{array}$ & 39.2 & 12.6 & 5.8 & 4.8 & 62.2 \\
\hline
\end{tabular}

V.3 Similarly, large amounts can also be raised via securitization of remittances, credit card vouchers, telephone receivables and airline ticket receivables by entities in developing countries. The 1998 balance of payments data show that net remittances of all low and middle-income countries combined amounted to $\$ 47.5$ billion. South Asia region was the biggest recipient of remittances hauling in $\$ 13.5$ billion followed by Latin America and Caribbean with $\$ 13$ billion. Assuming that 50 percent of remittances are channeled through banks and a conservative over-collateralization ratio of 5:1, securitizable remittances are as high as $\$ 4.8$ billion per year (see column 4 in table 5).

V.4 Credit card receivables arise from foreign visitors either purchasing goods and services or obtaining advance or local currency on ATM by charging their Master Card, Visa, American Express or other charge accounts. Local merchants take the resulting credit card vouchers to a local voucher-acquiring bank, which pays them cash. The voucher-acquiring bank then obtains dollars from Master Card, Visa and the like. ${ }^{18}$ In a structured transaction, the voucher-acquiring bank securitizes future flow credit card receivables. The potential for such future flow receivable asset-backed securitization can be gauged by adding up foreign visitors' total expenditures in developing countries. First approximation to such expenditures is obtained from the balance of payments data on net international travel receipts. As Chart 7 amply demonstrates, these have been substantial averaging \$24.5 billion from 1995 to 1997 . Assuming that one-half of foreign visitors' expenses are paid with credit cards, the securitizable amount of credit card vouchers is around $\$ 2.5$ billion per year. ${ }^{19}$

\footnotetext{
${ }^{18}$ For a specific example of such a transaction, see Appendix A.

19 Once again, we use a conservative over-collateralization ratio of 5:1.
} 


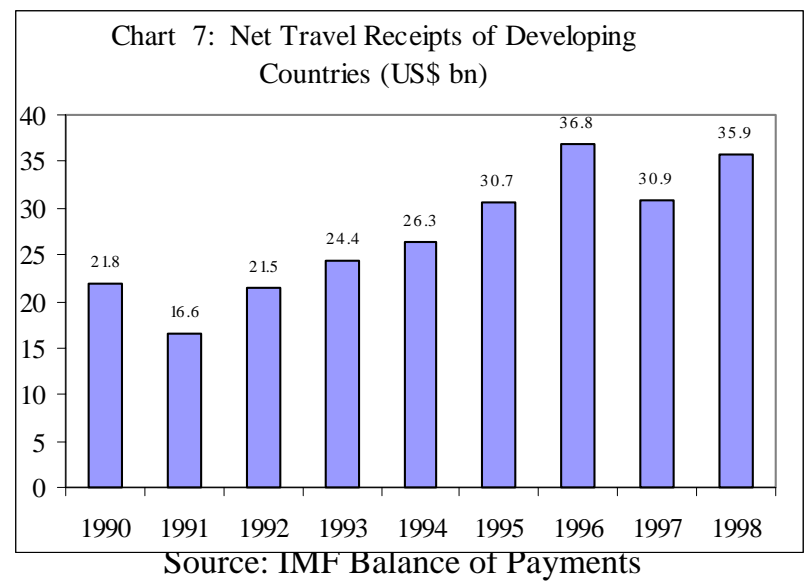

V.5 The opportunities to securitize telephone receivables are also believed to be quite sizable. Such receivables arise when a country has net incoming international calls which use the internal network of the call receiving country and for which telephone companies in the call originating country have to make payments. Thus, the receivables of a telephone company in a given country depend upon the net volume of incoming calls; i.e., incoming less outgoing calls. Net incoming international telephone calls of developing countries experienced a quantum jump in 1993 (possibly reflecting better data collection) and have risen steadily since then to average about 8 billion minutes from 1995 to 1997 (Chart 8). At the same time, however, the average peak rate settlement rate (between the United States and 34 countries) has fallen sharply from 78 cents per minute in 1993 to 41 cents in 1998. As a result, developing countries' net settlement receipts have actually fallen from $\$ 8$ billion in 1993 to $\$ 5$ billion in 1998, as Chart 9 shows. Additional rate reductions are expected and the internet poses yet another risk to the prospective net settlement receipts of developing countries. Still, developing countries should receive annually $\$ 3$ billion in net telephone receivables of which $\$ 0.6$ billion could be suitable for securitization annually.
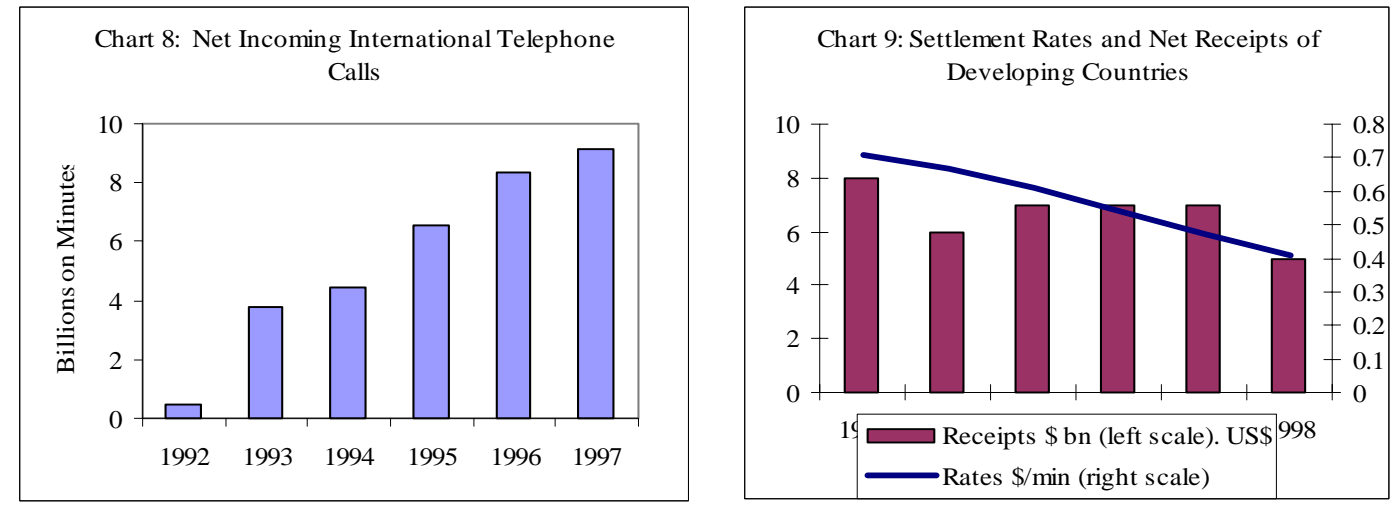

Source: ITU

V.6 In summary, the size of future flow receivables of developing countries-from oil, mineral and agricultural raw materials exports, and from remittances, credit card vouchers and telephone receivables - that are suitable for securitization could be over $\$ 65$ billion per annum (Table 7). Interestingly, Latin America accounts for a quarter of this potential size which is in sharp contrast to its absolute dominance at present (see 
table 5 earlier). This is not to imply that in Latin America the potential for securitization is exhausted. But this exercise indicates an enormous potential for growth of this asset class in other regions. In particular, the greatest potential seems to be in Europe and Central Asia region, which is rich in oil and minerals. Many countries in this region are also middle-income countries that need external financing. Several countries in the Middle East have large amounts of oil collateral that could potentially be securitized if these countries needed external capital. Countries in East Asia and Pacific (particularly Indonesia, Malaysia and the Philippines) also have large amounts of receivables that could potentially be securitized. In South Asia, the potential for this asset class lies in workers' remittances, credit card vouchers from tourism, and telephone receivables.

Table 7: Potential for securitization of developing country receivables by sector, 1998

\begin{tabular}{lc}
\hline & Billions of US\$ \\
\hline Oil Exports & 39.2 \\
Mineral Exports & 12.6 \\
Agricultural raw materials & 5.8 \\
Remittances & 4.8 \\
Credit Card Vouchers & 2.5 \\
Telephone Receivables & 0.6 \\
Total & $\mathbf{6 5 . 5}$ \\
\hline \multicolumn{2}{c}{ Source: Authors' calculations assuming over-collateralization } \\
\multicolumn{2}{c}{ ratio of 5:1. }
\end{tabular}

V.7 However, it is worth reiterating that this is not a 'forecast' of the size of this asset class in developing countries. Rather the objective of this exercise is to examine the constraints on such issuance, which is the subject of the following section.

\section{Constraints on Securitization}

VI.1 The actual future flow receivables-backed securitization has been and will continue to be much smaller than the potential given that a number of constraints are likely to be binding. First and foremost, the best candidates for future flow receivable secured transactions are typically investment grade issuers (in local currency terms) from below investment grade sovereigns. Securitization via an SPV structure and overcollateralization permits such transactions to escape the sovereign credit ceilings and obtain significant reductions in borrowing costs. Also, while many of the risks mentioned in section II can be mitigated through an appropriate structure, overcollateralization and hedging, certain elements of performance risk are difficult, if not impossible, to mitigate. Perhaps a good indicator of an entity's performance risk is its local currency rating (although, as discussed in section II, the going concern or survival assessment can exceed local currency rating).

Table 9: Distribution of Sovereign Foreign Currency

Ratings for Developing Countries, July 2000

\begin{tabular}{lcc}
\hline & Moody's & S\&P \\
\hline Rated & 59 & 47 \\
I-grade \& above & 21 & 19 \\
1 Notches below I-grade & 7 & 5 \\
2 Notches below I-grade & 4 & 6 \\
3+ Notches below I-grade & 27 & 17 \\
\hline
\end{tabular}

Source: Moodys and S\&P 
VI.2 Several countries in the low and middle-income group are either below investment grade or not rated at all (Table 9). ${ }^{20}$ But there are few issuers in these countries that have investment grade local currency ratings. In Mexico, for instance, $\mathrm{S} \& \mathrm{P}$ has rated only 12 companies investment grade; i.e. rating of BBB- or better in terms of local currency debt (Table 10). In Brazil, even though it is a much larger economy, there are just three investment grade companies in terms of local currency ratings due to the significant impact of the sovereign risk on the corporate sector. ${ }^{21}$

Table 10: Number of investment grade companies in below investment grade developing countries (local currency ratings)

\begin{tabular}{lclc}
\hline Country & $\begin{array}{l}\text { Inv. Grade } \\
\text { companies, } \\
\text { S\&P (Fitch) }\end{array}$ & Country & $\begin{array}{l}\text { Inv. Grade } \\
\text { companies, } \\
\text { S\&P (Fitch) }\end{array}$ \\
\hline Argentina & $15(6)$ & Mexico & $19(10)$ \\
Brazil & $3(3)$ & Malaysia & 11 \\
China & 2 & Nigeria & 1 \\
Colombia & $2(2)$ & Pakistan & 0 \\
Croatia & 2 & Panama & $3(2)$ \\
Czech Rep. & 12 & Peru & $1(1)$ \\
Egypt & 9 & Philippines & $4(1)$ \\
El Salvador & $2(2)$ & Poland & 8 \\
Estonia & 1 & Slovenia & 1 \\
Hungary & 6 & Thailand & 6 \\
India & 5 & Tunisia & 3 \\
Jordan & $0(1)$ & Turkey & $0(5)$ \\
Korea & 6 & Uruguay & 2 \\
Lebanon & 0 & South Africa & 13 \\
\hline
\end{tabular}

Figures outside the parentheses indicate S\&P local currency rating as of June 20, 2000 and those inside parentheses indicate rating by Fitch as of July 2000. Investment grade defined as BBB- or higher rating by S\&P and Fitch. Chile is excluded because it has long been an investment grade country.

Source: Standard \& Poor's and Fitch

VI.3 There can be certain operational or legal provisions through which a future flow receivable transaction can obtain a credit rating above the company's local currency rating. Rating agencies have assigned such elevated ratings to several transactions, which rely on the future generation of telephone receivables by state-owned telephone companies. Also several transactions that rely on the future generation of airline ticket receivables by flagship carriers under long-term contracts with credit card companies have also been assigned ratings above both the sovereign ceiling and the carrier's local currency rating. Needless to say, obtaining such elevated ratings entails costs as well as a likely loss of flexibility for the issuers.

\footnotetext{
${ }^{20}$ Dadush and Dasgupta (1999) also find that the sovereign debt of more than three-fourths of 51 developing countries is rated below minimum investment grade.

${ }^{21}$ Reasons include volatile growth, devaluation risk and high interest rates as in early 1999, and also the fact that many Brazilian companies hold substantial amounts of government bonds in their portfolios and acquire in the process the sub-investment grade rating of the sovereign.
} 
VI.4 While investment grade issuers in below investment grade countries are the best candidates for future flow asset-backed deals, it is essential that the issuer countries provide certain institutional and legal protections if such deals are to occur. In general, it is difficult to structure securitized transactions in countries that have few laws on their books. Typically, less law implies greater doubt and uncertainty which makes it more difficult to structure a deal. Bankruptcy law, in particular, is crucial for securitized transactions. Ideally, the bankruptcy law should permit "true sale" of a future flow asset. But it is possible to structure a securitized transaction by examining the country's history of adherence to existing laws or if the law is ambiguous enough to permit a "true sale" opinion. $^{22}$

VI.5 Issuers are often reluctant to embrace asset-backed financial mechanisms not only because they may erode financial flexibility but also because they are viewed as undesirable in themselves (see Box 3). Many issuers are concerned about the burden of full disclosure of information in a timely fashion. Others worry about whether the use of future flow secured bonds will taint their creditworthiness. After all, such issuance reflects a tacit admission that the "normal" unsecured debt mechanisms are unavailable to them. Some issuers also worry that pledging future assets may breach the covenants on their existing unsecured bonds. ${ }^{23}$

\section{Box 3: Failed Deals}

There are difficulties in defining a "failed" deal, but according to rating agencies such as Fitch and $\mathrm{S} \& \mathrm{P}$, deals generally fail at the very beginning of the process. The failure rate for deals that are under preparation for a few weeks is rather low. Thus, a launch is more often postponed rather than cancelled. A postponement can result from the perception that the spreads are too high and may come down in the future. A decision to postpone may also be triggered by an unexpected downturn in market conditions.

Nevertheless, some deals do fail to materialize. A major reason for failure is the discovery by the issuing entity that it does not have or does not wish to reveal certain critical information. Internal reorganization of an issuer can also result in a securitized deal being scuttled. Lack of certainty about the legal system and opinion is also known to have stopped deals from proceeding. In Asia, issuers may have attached a stigma to pledging future receivables, thereby limiting the use of this asset class.

VI.6 Another significant constraint on the issuance of future flow receivable backed securities comes from the long lead times and very specialized skills involved in putting together structures that mitigate various elements of risk and allow rating agencies to rate these bonds above the sovereign ceiling. The long lead times - often anywhere from 6 months to over one year - deter investment banks from pursuing such deals aggressively. Also, the inability of issuers to tap this asset class on demand means that the preparation for the issuance of such bonds has to begin well in advance, often before a crisis emerges

\footnotetext{
${ }^{22}$ But if a developing country were to adopt the U.S. bankruptcy code which does not give creditors access to future flow assets once a bankruptcy petition is filed, the potential for future flow securitizations from that country is likely to be greatly reduced.

${ }^{23}$ For instance, this was one of the concerns of Argentina's YPF which was the possibility of launching an asset-backed deal in 1995.
} 
and shuts down unsecured access to international capital markets. Thus, the long lead times make the spread advantages of future flow asset-backed securities difficult to assess with any degree of certainty and precision.

VI.7 The specialized skills necessary to structure asset-backed transactions together with the long lead times also imply that promoting this business becomes an expensive proposition for investment banks and issuers who eventually bear these costs. Legal costs involved in structuring these transactions are reported to be particularly steep at about $\$ 2$ million to $\$ 3$ million per transaction and may deter many issuers from using this financing mechanism.

VI.8 The high costs described above are fixed in nature. Thus, future flow-backed issuance become affordable when large amounts are raised. Consequently, only large issuers who can justify raising large amounts of financing in the international capital markets are expected to be viable candidates for this asset class. A paucity of such entities among developing countries is, therefore, yet another constraint on the growth of this asset class.

VI.9 Not having issues of significant size is often cited as a reason for the lack of liquidity in this asset class. Only a handful of asset-backed securities from developing countries such as those from Pemex and PDVSA are known to be reasonably liquid. But lack of liquidity does not seem to be a significant deterrent to certain class of investors, particularly insurance companies. Insurance companies are typically "buy and hold" investors. They also feel that liquidity is highly overrated since bonds that are liquid in good times can suddenly become illiquid once a crisis sets in.

\section{Public Policy Issues}

VII.1 In this section, we explore the scope for public policy initiatives to lift some of the constraints on the issuance of future flow-backed securities from developing countries. As noted earlier, the ideal candidates for future flow receivable-backed securitizations are investment grade entities (in local currency terms) in sub-investment grade countries (in foreign currency terms). The binding constraint on issuance in this context comes from the dearth of investment rated entities in developing countries.

VII.2 The current paucity of corporate ratings in developing countries is owed at least in part to the costs that corporations have to incur to secure ratings from the international credit rating agencies. Two types of costs are involved - (1) those associated with timely, frequent (quarterly) and reliable reporting of financial information, and (2) the out-of-pocket costs payable to the rating agencies. While the first set of costs is difficult to reduce, establishing indigenous rating agencies can slash the out-of-pocket costs. The existing indigenous rating agencies reportedly charge one-third or less of what companies have to pay to the international rating agencies and provide ratings that can be used only in domestic capital market transactions. Apart from lower out-of-pocket costs, the indigenous ratings should be a good steppingstone to obtaining international credit 
ratings, because companies with domestic ratings will certainly save time needed to obtain an international credit rating. ${ }^{24}$

VII.3 High legal costs associated with structured transactions is a second constraint on the growth of this asset class. Since the costs involved in clarifying the legal/institutional framework can be particularly high prior to the first securitized issuance from a country, a multilateral institution such as the World Bank can perhaps provide the seed money to underwrite these high costs. It can also give legal support to developing country issuers of structured bonds. For example, it could help develop standardized templates for certain types of securitizations. It is believed, for instance, that bonds backed by future exports of oil (Pemex and PDVSA deals) are not highly complex to structure and hence are amenable to a cookie-cutter approach.

VII.4 Given the high costs of obtaining legal, investment banking and credit rating services, the size of future flow securitization deals have to be large to be cost-effective. ${ }^{25}$ But many developing countries have few entities that can justify raising large sums of money. This size constraint can be escaped by using the master trust arrangement. ${ }^{26}$

VII.4.1 Using a master trust arrangement, an issuer can structure a deal for a large transaction but tap the capital market in several tranches over time. Recently, the Pemex Finance Limited used such an arrangement when in 1998 it secured agency rating for \$6 billion in structured finance and then undertook issuance in several tranches under this facility. This is a skillful use of structured finance to raise funds as and when needed while minimizing the costs associated with arranging such transactions.

VII.5 Long lead-time is another constraint on the growth of this asset class- the Pemex Finance deal took 18 months from conception to red herring. As noted in section VI, long lead times raise costs, discourage investment banks from pursuing this business, and reduces its usefulness as a financing mechanism during a liquidity crisis (which tends to be highly unpredictable). Like high legal and structuring costs, the long lead times can

\footnotetext{
${ }^{24}$ Of course, indigenous credit ratings often lack credibility because local agencies are perceived to be too close to the issuers. There is also the problem of mapping local rating scales into (widely accepted) international rating scales. Clearly, local agencies will have to earn their stripes by doing diligent credit assessment and putting credits to strenuous stress testing. There is no reason, however, for local agency ratings to gain wider currency and provide a useful bridge to international credit ratings for issuers from developing countries.

${ }^{25}$ For example, raising \$200 million through asset-backed securitization can lead to a saving of more than $\$ 5$ million in interest costs over a four year period-and more than $\$ 11$ million over a seven year periodif the spread is 50 basis points lower than a comparable unsecuritized transaction. If the spread is lower by 200 basis points, savings would rise to $\$ 20$ million and $\$ 44$ million after 4 years and 7 years respectively. Thus, even if fixed costs of securitization are high, savings over the term of such borrowings far outweigh such costs.

${ }^{26}$ Receivable pooling may be a second method of overcoming the small issue size constraint. Telephone companies in several Caribbean countries, for instance, could pool their net telephone receivables from international calls and securitize a large enough issue. Similarly, several banks from one country or banks from several countries could get together and securitize their pooled credit card vouchers. However, structuring such pooled transactions will be more complex than structuring receivables of a single issuer and the question of more creditworthy entities within the group subsidizing the less creditworthy entities will undoubtedly arise. Perhaps such deals could be done on a highly selective basis.
} 
also be truncated through a systematic effort to provide issuers with legal and structuring assistance. After all, structuring such deals requires very specialized skills. To ensure low cost funding via future flow-backed securitization in times of crisis, potential issuers should be encouraged to enter into a master trust arrangement a la Pemex Finance. We pursue this idea further below.

VII.6 Limits on available resources is compelling multilateral lenders to focus more on low income developing countries while letting middle income countries depend more on private capital markets. This approach works in tranquil times. But when a financial crisis erupts, middle income countries lose access to private capital markets. The multilateral institutions are then called upon to participate in multi-billion dollar rescue packages for middle income countries like Mexico, Korea and Brazil; and their ability to support programs in low income countries is inevitably hurt. Keeping large structured finance deals waiting in the wings may be a good alternative. Multilateral institutions can consider providing seed money and technical assistance for such contingent private credit facilities. $^{27}$

VII.7 Absence of an appropriate legal infrastructure is yet another constraint on the issuance of future flow-backed securities. Developing countries should be encouraged to establish the necessary laws to overcome this constraint. Instead of attempting a grand overhaul of the legal system, countries should be encouraged to have a focused approach. The most crucial law is one governing bankruptcy. It is even more vital that the bankruptcy law allows the pledged assets to remain pledged in the event of default. Beyond the bankruptcy code, developing countries should be encouraged to follow the general rule that "more is better" since less law means more doubt and greater cost in structuring securitized transactions.

VII.8 Finally, multilateral institutions can also play a role in educating public sector bureaucrats and private sector managers in developing countries on the role that this asset class can play in times of crisis and how to best identify and structure future flow-backed transactions.

VII.9 A potential concern about this asset class is related to the issue that it represents relatively inflexible debt. As a result, its growth beyond a certain level may undermine the sovereign's own creditworthiness and increase borrowing costs. In this case, the cost savings via securitization may be offset and perhaps even exceed the increasing costs of sovereign plain vanilla debt issuance. While this is a valid concern, the present issuance of securitized debt does not appear to have approached this critical level. For instance, rating agencies have not downgraded the sovereign credit ratings of either Mexico or Venezuela on account of their rising securitized debt. These two countries have been most aggressive in issuing securitized debt. Mexico's securitized debt of $\$ 19.3$ billion is

\footnotetext{
${ }^{27}$ Future flow securitization can potentially conflict with the negative pledge provision included in IBRD loan and guarantee agreements. This provision does not prohibit the creation of security in favor of other creditors. Instead, it prohibits the establishment of a priority for other debts over the debt due to the IBRD. However, the IBRD may grant a waiver in respect of this clause in certain circumstances, in particular, when transactions involve small amounts (World Bank Operational Manual OP7.20).
} 
about 16 percent of its total debt and Venezuela's securitized debt of $\$ 6.1$ billion is 18 percent of its total debt. Thus, it appears that securitized debt can rise to around 15 percent of total debt of a developing country without necessarily jeopardizing the sovereign's overall creditworthiness. Nevertheless, such debt combined with debt from other preferred creditors can reduce the ability of a borrower to service debt.

VII.10 Establishing a pipeline of future flow securitization deals can provide a developing country a way of accessing markets during times of liquidity crisis. The resultant preservation of and improvement in productive capacity can protect a country's creditworthiness and keep down its borrowing costs. There are also significant externalities associated with future flow deals. By clarifying the legal and institutional environment surrounding a developing country issuer, such deals can pave the way for future deals by other issuers as well. Because of their investment grade rating, future flow deals attract a much wider class of investors than unsecured deals. Thus, future flow deals can improve market liquidity and reduce market volatility. That can generate the added interest on the part of international investors in other asset classes or other borrowers. 


\section{REFERENCES}

Caballero, Ricardo. 2000. "Aggregate Volatility in Modern Latin America: Causes and Cures." Paper prepared for the World Bank report "Dealing with Economic Insecurity in Latin America." May.

Dadush, Uri, and Dipak Dasgupta. 1999. "The Benefits and Risks of Capital Account Liberalization." The World Bank. Processed.

Fitch IBCA, Duff \& Phelps. 1999a. "Future-Flow Securitization Rating Methodology." Fitch IBCA, Duff \& Phelps, March.

Fitch IBCA, Duff \& Phelps. 1999b. "DCR's Approach to Rating Existing Trade Receivables Transactions in Emerging Markets.” Fitch IBCA, Duff \& Phelps. April.

Fitch IBCA, Duff \& Phelps. 1999c. "Under Pressure: Structured Transactions in Emerging Market Stress..” Fitch IBCA, Duff \& Phelps. April.

Fitch IBCA, Duff \& Phelps. 2000a. "Rating Securities Backed By Financial Future Cash Flows." September 25. www.fitchratings.com.

Fitch IBCA, Duff \& Phelps. 2000b. "Rating Securities Backed By Future Export Receivables." October 10. www.fitchratings.com.

International Monetary Fund. Balance of Payments Statistics, Various issues.

Izquierdo, Alejandro. 2000. "Credit Constraints, and the Asymmetric Behavior of Asset Prices and Output under External Shocks," The World Bank. Mimeo. June.

Morgan Stanley Dean Witter. 2000. “Pemex Finance Ltd. Offering Memorandum.” February.

Standard \& Poor's. 1999a. "Securitization in Latin America 1999." Structured Finance at Standard \& Poor's.

Standard and Poor's. 1999b. "Lessons from the Past Apply to Future Securitizations in Emerging Markets." July.

Standard \& Poor's. 2000. "Bank Survivability Criteria Aids Future Flow Issuers." Standard \& Poor's CreditWeek. September 27.

Standard and Poor's. Structured Finance: Emerging Markets Criteria.

World Bank. 1999. World Development Indicators. Various issues.

World Bank. 2000. Global Development Finance. 


\section{Appendix \\ Two Examples of Securitization Structures}

\section{(1) Banco de Credito del Peru's securitization of credit card receivables.}

Amount \$100 million, Issue Date 11/12/1998, Maturity 11/14/2005, Future US dollar receivables owed to Banco de Credito del Peru by Visa International. Credit Rating AAA from S\&P.

Credit card holders travelling to Peru buy goods and services or obtain advance or local currency on ATM. The merchants sell the resulting vouchers to a local voucheracquiring bank, which pays them cash. The voucher-acquiring bank then obtains dollars from Visa.

In a structured transaction, the voucher-acquiring bank (Banco de Credito del Peru, in this instance) issues irrevocable instructions to the credit card company (Visa, in this instance) to transfer all future payments on credit card vouchers to an off-shore account under the control of a trustee. The trustee uses the monies paid into this account to make payments to the bondholders. This structured transaction is not subject to the same sovereign risks as unstructured transactions.

As Exhibit A-1 shows, the BCOL Master Trust, which receives payments from Visa, is outside the Peruvian jurisdiction. The first claim on BCOL is from the bondholders. The Peruvian Central Bank is not involved in the process. After paying principal and interest to the bondholders, the excess Visa payments on vouchers are paid by BCOL Master Trust to Banco de Credito Overseas Ltd. in the Bahamas which in its turn pays the excess to Banco de Credito del Peru in Peru. The proceeds from the issuance of the structured bonds flow to Banco de Credito del Peru via BCOL Master Trust and Banco de Credito Overseas Ltd. in the Bahamas.

While this structure mitigates the usual convertibility and transfer risks, two risks still remain. First, there is the risk of fluctuations in the volume of vouchers due to (a) variation in tourism, (b) relations with vendors, and (c) devaluation of Peru's currency, nuevo sol. Second, there is the risk of Banco de Credito del Peru becoming insolvent. These risks can be reduced (not eliminated) through excess collateral. The rating agencies examine the data on tourist arrivals/expenditures and subject it to stress tests. The results of these tests are used to determine the necessary excess coverage. In the case of Banco de Credito del Peru, the amount of future flow receivables transferred to the BCOL Master Trust were set at 2.5 times the debt service requirements. The structure described above plus the excess collateralization resulted in the transaction receiving a AAA credit rating from $\mathrm{S} \& \mathrm{P}$ as opposed to the $\mathrm{BB}$ sovereign credit rating of Peru in 1998. 
Exhibit A-1: Banco de Credito Overseas Ltd.

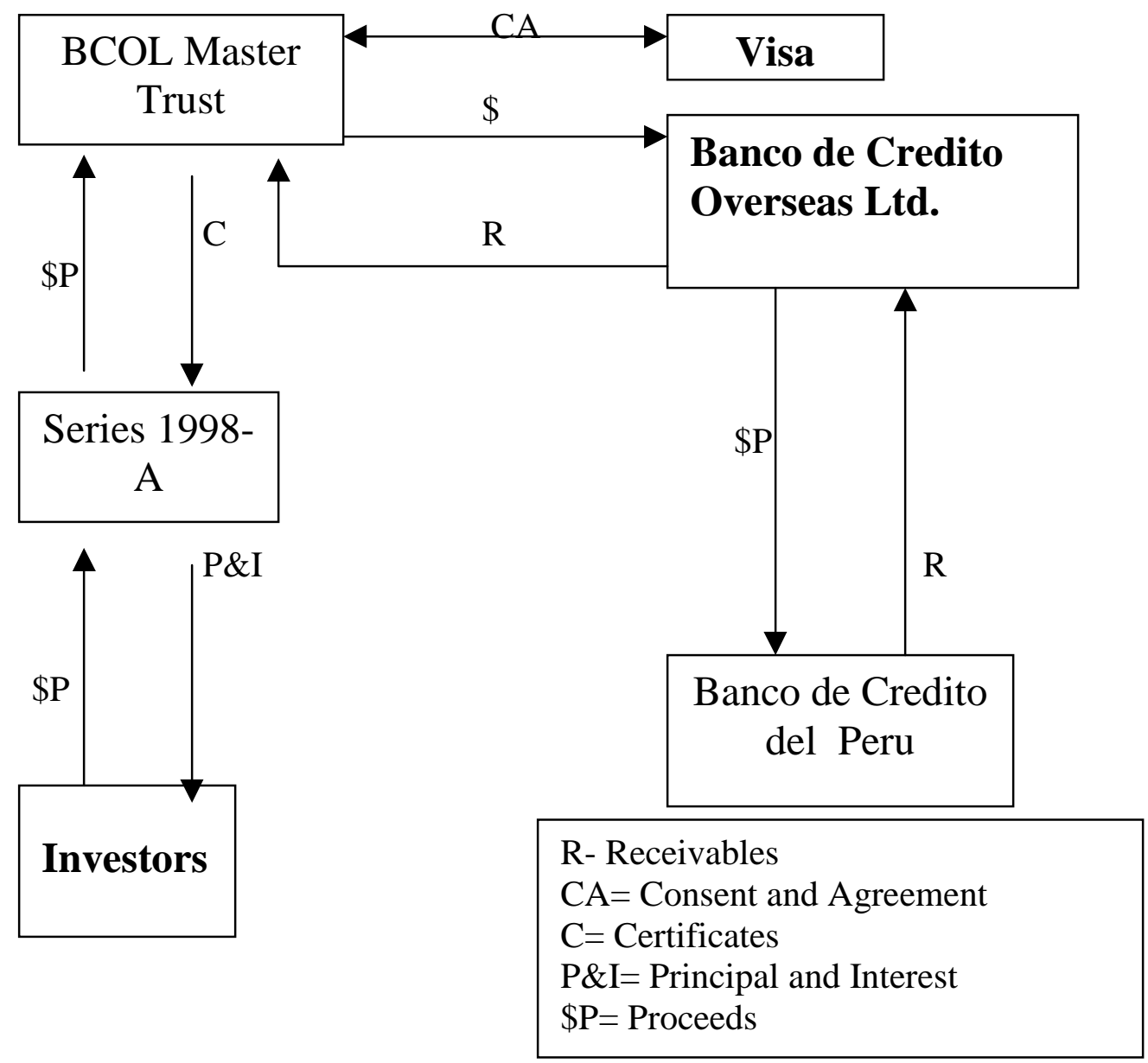

\section{(2) Pemex Finance Limited Securitization of Crude Oil Receivables}

Amount: Nine issuances during 1998 and 1999, each up to $\$ 500$ million. Future US dollar receivables owed to Pemex Finance Ltd. by designated customers who will receive Mayan crude oil from Pemex Exploracion y Produccion (PEP), via Petroleos Mexicos Internacional (PMI). Rating BBB.

PMI arranges to sell Mayan crude oil, or some other crude oil type if Mayan becomes unavailable, to designated customers who agree to deposit their payments into an offshore collection account. PMI, a subsidiary of Pemex, is the distributor for Mayan crude oil, which is produced by PEP. Pemex Finance Ltd. is the offshore issuer of notes. It purchases the receivables from PMI via the offshore Pemex subsidiary, PMI Services.

Figure 1 shows that sales of the crude oil to designated customers and of receivables to PMI Services are out of the jurisdiction of the Mexican government. The first claim on the receivables is from the note holders, and the Mexican central bank is not involved in the process. Chase Manhattan Bank has agreed to administer the issuance of all debt and 
the payment of interest and principal on such debt in accordance with Pemex's agreements. After paying note holders principal and interest, excess payments, based on fluctuation in crude oil prices, are paid to PMI Services and PMI, via the offshore collection account.

While this structure mitigates the usual convertibility and transfer risks, other risks still remain. Primarily, there is a risk that a fluctuation in crude oil prices will result in revenues insufficient to cover the interest and principal due to note holders. The overcollateralization of the notes minimizes this risk - PMI will provide a minimum coverage ratio of three times the amount needed for payment of interest and principal. Designated customers have also signed agreements acknowledging their commitment to purchase crude oil and to make any future payments into the offshore collection account. Further enhancing the strength of such issuance is Pemex's track record of timely servicing of debt in the past. As a result of these enhancements, S\&P rated the credit of 1998 and 1999 tranches A-2 and A-4 and 1999 tranche A-5 as BBB. Rated as AAA are 1998 and 1999 tranches A-1 and A-3, as they are insured by MBIA and AMBAC. These ratings are clearly favorable relative to the $\mathrm{BB}$ foreign currency rating of the United Mexican States.

Exhibit A-2: Pemex Finance Ltd. Structure

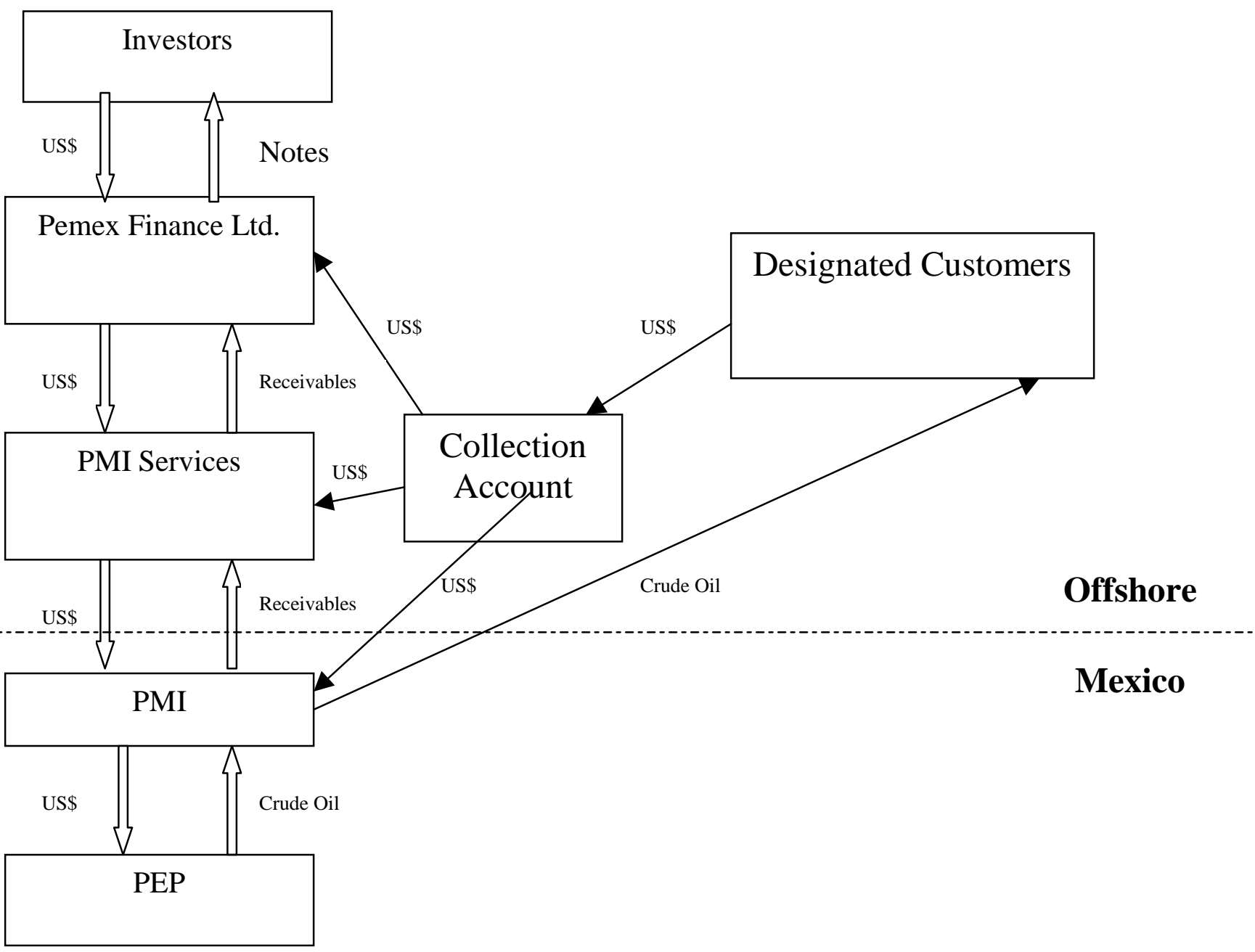

